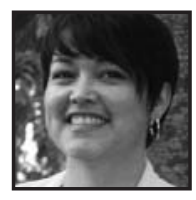

\title{
Stepping-Stone or Saving Story?
}

\author{
Trudy Cardinal, University of Alberta
}

\section{ABSTRACT}

Why does one enter graduate studies? What does it mean to do research on Indigenous education as an Aboriginal person? What is the significance of attaining a master's degree? In this paper I speak to how the experience of inquiring into the educational stories of five of my relatives, and into my own lived experiences, helped me understand the importance of stories and the impact of the autobiographical narrative inquiry on myself and my family.

\section{Master's Research: Stepping-Stone or Saving Story?}

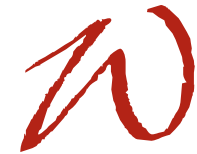

hy does one enter graduate studies? What does it mean to do research on Indigenous education as an Aboriginal person? What is the significance of attaining a master's degree? These questions became important because in my graduate studies I experienced many tensions. Some tension revolved around choosing a research topic that would make a real difference in the lives of Aboriginal people. Other tensions revolved around my own feelings of belonging and identity. I doubted my ability to find the strength to carry the weight of stories I would be told as a researcher, and I wondered if I, a non-Cree speaker, distanced from the extended family and my mother's home community, was Indigenous enough to do Indigenous research. In the midst of my studies, while I pondered these questions and struggled to negotiate the tensions I felt around the questions, I was told that a master's degree was merely a stepping-stone to attaining a Ph.D. and not worth such soul-searching internal debates and especially not worthy of too much time out of my life. This "stepping-stone" phrase constantly bumped up against my lived experience, and I decided that if I was to feel confident engaging in Indigenous 
research, then I needed to make sense of the tensions I was experiencing. Switching focus, I selected an autobiographical narrative inquiry as an appropriate avenue into my experiences as an Aboriginal student trying to become an Indigenous researcher. The process and product of the autobiographical narrative inquiry (Clandinin \& Connelly, 2000), and the space created for the inquiry into my stories and into the educational stories of five of my relatives, helped me understand the importance of stories and the impact of the autobiographical narrative inquiry on myself and my family.

My research puzzle centered on my questions about the responsibilities of an Aboriginal graduate student choosing to engage in research with Aboriginal peoples in ethically responsible ways. The field text for the inquiry included two years of graduate studies writings: final papers, response journals, assignments, and life writings. As I moved from field text to research text, I identified tensions and bumping points I experienced in coming to understand Indigenous research. As I read, reread, and inquired into the field texts, I began to develop a deeper understanding of the impact of these moments on my identity, my stories to live by, as researcher in the making, and on my sense of belonging.

One of the field texts included writings about the final course in my graduate program, which required me to engage in a small research project with an Aboriginal community on the topic of Aboriginal education. The task was to seek out people's stories and determine common themes, to discover what issues in Aboriginal education existed for that particular community. As I pondered what this meant, I experienced the tension of imagining going to an Aboriginal community with which I had lost close ties and suddenly becoming interested because I had a need to fulfill a course requirement. Because of the short time frame, I knew I would not have time to reconnect and build relationships to the families who lived in the communities I imagined contacting. Building relationships was an essential piece of good research in both narrative inquiry ${ }^{1}$ and Indigenous research. ${ }^{2}$ These concerns pushed me to rethink the image of community that I held and to broaden the definition. I began to think of the little community of female relatives that I had constantly sought out in my studies to compare the university view of Aboriginal issues against the lived experiences of these trusted women. I returned to the core group of family members who had come along on my research journey. They were the ones who were always trusting and willing to give me their stories. They came because they wanted to help me and wanted to come to an understanding together. They also came in relationship. I returned to the women who had volunteered to join me every time I had a research assistantship that needed Aboriginal participants. They willingly 
answered my questions and laughed with me at my initial awkwardness and my toooften repeated use of the word "right" when I was trying to remain a neutral, objective researcher. I realized that, as Aboriginal women living in an urban setting and connected through familial ties and a shared early landscape, we formed a community. We were not as close as we had been as children, and we were only getting to know each other now as adults. However, I felt the trust I had in the lived experiences and knowing of these women as well as the relationships we had formed were all necessary for me to engage in ethical and responsible research with Aboriginal people on Aboriginal topics.

In choosing these women as my community, I negotiated a way to feel less tension engaging in research that was personally so very close. As an Aboriginal woman, mother, aunt, teacher, and family member engaging in research on topics involving Aboriginal issues in education, I found the task to be complicated and tension filled. As I pondered statistics that predicted a "lifetime of poverty" for the disproportionately high number of Aboriginal youth who would not graduate, I saw the faces of loved ones and family members filling those categories (Mendelson, 2006, p. 24). I felt distress and panic. I was also uncomfortable feeling the responsibility held in the little flickers of hope and faith that I imagined existed in those who believed that through my research I would be able to answer these hard questions and bring understanding to our lived experiences as Aboriginal students. In narrative inquiry, relationships and coming alongside of participants is key (Clandinin, 2006, p. 48). As the trusted women became participants, they also became co-researchers. Together, we composed an understanding of lived experiences through the retelling, the narrative inquiry into the lived and told stories (Clandinin \& Connelly, 2000). In the conversations between myself and my relatives on their education experiences as children, as adult students, and as mothers or aunties, we came to understandings that were more valid than inquiries into the experiences of people with whom I had no relationships. I came to better understand the process of narrative inquiry, a process that allowed time to inquire into each story alongside my participants. Most importantly, I felt less tension as an Indigenous researcher who felt disconnected from her Aboriginal roots when I worked alongside friends and family.

While narrative inquiry provided a way to work around some of my unease, I quickly realized how naive my understanding of the complexities of engaging in research with humans really was. I was reminded of how all research projects exist in the midst of lived lives (Clandinin \& Connelly, 2000, p. 20) when life did intervene in the middle of my little research project. The day I finished interviewing the second of my planned five participants, family tragedy struck. A cousin unexpectedly died. I 
abandoned the research for a week and headed home to join my loved ones. Together we rallied to cope with this latest loss. This gathering together in ceremony, remembering and honouring the life of a loved one, tightened the bonds that united us and brought us even closer as a family. I recall gathering at the community hall, surrounded by the family and friends from whom I had felt so disconnected the week before. I felt again the strong bond that still existed in their welcoming, open arms for all who gathered that day. My course work faded far into the background, and the lived experiences of the family who had lost a mother, a sister, a cousin, a friend, and a loved one made me stop and question again what it meant to be an Indigenous researcher and what impact research, even mine, would have on these humans for whom I cared so deeply.

I eventually completed the final three interviews. In the inquiry space created with the same family members touched by this recent death, relationships were key. The conclusions I reached and the paper I wrote attempted to honour the sacredness of the stories told. With care and tenderness, I wrote to understand and to respect the gift of stories I had been given. I wrote to give back to those who always, for the two years of graduate study and for much of my life, gave so willingly to me during processes of becoming graduate student, researcher, and Indigenous scholar. The seriousness of research and the necessity of ethical considerations became very clear as I sat alongside relatives while finishing interviews with the grief of our most recent loss fresh in our hearts (Kahakalau, 2004).

Loppie's (2007) words help me describe the process I engaged in with this final course project. I found it

both intellectual and intuitive ... based on my relationship with the women [and] evolving knowledge and understanding of [Indigenous education].... This process was also emotionally, psychologically, and spiritually laborious, because it required the prolonged and intimate engagement of my consciousness regarding the challenges continuing to face Aboriginal women [who were an intimate part of my extended family]. According to Indigenous scholars (Battiste, 2002; Castellano et al., 2001; Smith, 2000), this engagement of multiple capacities is crucial to learning, particularly with respect to the historical and sociopolitical context of Aboriginal women's lives. (p. 277)

That paper I wrote represents some of the understanding I was beginning to develop when I finally allowed myself to be in relation as I sat across from a 
research participant and asked her hard questions about her educational stories. Sometimes there were tears, sometimes there were difficult stories to hear and to tell, often there was laughter, and always there was caring. I inquired into this experience carefully because of the deep impact it had on my understanding of both narrative inquiry and Indigenous research and the impact it had on me as a person. The conclusion I reached in the paper represents some of the knowing I came to in two years of graduate studies. I had yet to engage in the autobiographical narrative inquiry process in my thesis study when I wrote that paper. But as I look back, I note how I attempted to take a moment of reflection within this final class project to try to articulate my emerging understandings. These initial comments, reflecting the thinking I engaged in during that time, were a part of what drew me further into the idea of an autobiographical narrative inquiry into my graduate studies experiences.

In this class project, I had a beginner's understanding of the methodology of narrative inquiry and of the methodological principles of Indigenous research. However, I tried in that short time to honour the elements that drew me to these methodologies, which are coherent and overlapping in ontological principles. I attempted to build relationships, to gather stories, and I searched for awareness of stories to live by within the inquiry process. Through my lived experience, my readings and the gathering of stories read, reread, and relived, I came to some deeper understanding. I sought out the impact of those grand narratives, always trying to see "big" and "small" (Greene, 1995). Above all, I tried to honour the "being" of the "other" while I read, reread, and revisited the stories co-composed in visits, as well as in the lifetime of our relationships (Stewart-Harawira, 2005, p. 156). I searched for common threads within the narrative, and I began to create research texts, always checking back to make sure that I continued to "honour the 'being' of the 'other'" (StewartHarawira, 2005, p. 156). While I was early in my understanding of what inquiring narratively entailed, and how similar in relational ontologies it was to Indigenous research, I wanted to emulate the kind of understanding that could be gained through narrative inquiry.

Wilson (2001) wrote,

As a researcher you are answering to all your relations when you are doing research ... you should be fulfilling your relationships with the world around you. So your methodology has to ask different questions: rather than asking about validity or reliability, you are asking how am I fulfilling my role in this relationship? What are my obligations in this relationship? (p. 177) 
I truly do imagine all my relations reading what I come to understand and come to write about. It is to them I go to most to seek approval. In this last class research project, I carefully considered who my community was and how I was going to ensure they too benefited from the research process. This felt coherent with the understandings I'd come to in the two-year graduate studies process. I chose my community thinking about Cajete's (1994) concept of community as "the place where the forming of the heart and face of the individual as one of the people is most fully expressed" (p. 164). My community of chosen go-to girls was a community in which I did feel "one of the people" (p. 164), and it was to these women that I was accountable in the writing of the paper. This close inquiry into this lived experience, this giving importance to my own story and honouring the stories of the women from my community, allowed me to begin to understand what kind of a researcher I needed to be and how important the relational aspect was. I began to see how narrative inquiry could be a way to negotiate the tensions I continued to feel with the label "Indigenous researcher" and my guilt at having drifted away from my traditional roots and my Aboriginal culture. I began to believe that I could still engage in research that would benefit the lives of Aboriginal people.

I tried to capture the spirit I strive to attain when engaging in research about Aboriginal education alongside Aboriginal people with the title of my thesis, "For All My Relations." Thinking about all my relations also helps me to work through the tensions and stay on a research landscape despite the dis/ease and discomfort I continue to experience. From this research experience, alongside five of my female relatives, and inquiring narratively into my experiences, I learned that I cannot speak for the family who stayed on the reserve. I cannot fully understand their stories in the same ways I can for those of us whose ties were weakened, who drifted away from the extended family and were set adrift in an urban setting. As an Aboriginal person, I learned that my community can and does include family who show up when they are needed: women who are my go-to girls, who are expert in the lives they live as Aboriginal people, and whom I bounce the university's ideas off of to test their validity. I learned that from my community's perspective, the issues in education extend far beyond the walls of the institution of school. These issues go deep inside to that shaky "wounded learner" 3 and far and wide to a society that initially learned about Aboriginal people as half naked on the shores, in awe of the big boat that was arriving to bring destruction and forever change their future. Addressing issues in Aboriginal education includes needing an authentic look at history, an accurate portrayal of where we, as Aboriginal peoples, are today-success stories, political structures, a living, breathing, evolving people-and continued hope for that future. The future as represented by those babies who laughed, cried, and snuggled as I 
questioned their mamas about issues in Aboriginal education. In the midst of our loss, in the midst of my research, in the middle of our interviews, I saw again, looming large, those smallest members of my community. As I hugged their wee little bodies and I smooched their smooth chubby cheeks, I knew that the words I heard in my Indigenous research class, those words about benefiting the community, about respect and relationship, were so very true. I can't be an objective researcher for this topic. I can't present on it as if I don't live it and as if the "can't lose another generation of children" 4 isn't speaking about me and mine. From this research process I am transformed-by loss, by hope, by the love of a family who statistically represent all the crappy stuff we hear about-but also by a family I am very proud of, for their sheer strength, their beauty, their determination, and especially their love of their babies for whom we do research to try to change a statistically predetermined future.

My awareness of how much narrative inquiry methodology creates safe places for stories to exist and be told and inquired into, and how important these safe places are for Indigenous researchers and participants alike, has grown. I realize how much I need these safe places for the sharing of personal stories and for the support I need to care for them in the way they need to be cared for. Lopez (1990) wrote,

Remember only this one thing. The stories people tell have a way of taking care of them. If stories come to you, care for them. And learn to give them away where they are needed. Sometimes a person needs a story more than food to stay alive. That is why we put these stories in each other's memory. This is how people care for themselves. (p. 48)

This caring of my participants and their stories was always important to me, but until I sat there in person, realizing the level of trust my participants had to share the stories they did, I had not realized the truth of what Lopez spoke.

Narrative inquiry and Indigenous research, and the relational aspects that both methodologies hold dear, create an in-between place where together participants and researchers can begin to see possibilities of how to negotiate tensions between who they have been in the past, who they are now, and who we are becoming while in the midst of research. I look to the words of Barton (2004), who wrote,

I have discovered that narrative inquiry is about interpreting the threads of life woven in the fabric of our daily lives. Narrative inquiry is about eliciting from life stories the insight, essence, and resonance that accompany our philosophical and cultural expressions and our desire for them to be 
recognized. As a methodology congruent with Aboriginal epistemology, narrative inquiry could be about witnessing an insurgent effort by Aboriginal people to reclaim confidence in their identities, regain a political voice, and heal from colonial injustices of the past. It is about a whole life. (p. 525)

Before engaging in autobiographical narrative inquiry, I felt daunted by the responsibility of engaging in Indigenous research and worried about my abilities to uphold the principles of ethical and caring research I was learning. I certainly did not feel that I had a valid voice, nor was I confident in my own identity as an Indigenous researcher or even as an Aboriginal person.

Through the process of narrative inquiry, keeping close the principles of Indigenous research methodologies, I articulated the understandings I was coming to and how engaging in narrative inquiry helped me to negotiate these tensions. Through narrative inquiry, I found a way to show "respect through cultural protocol" while still learning what this entails within my family (Archibald, 2008, p. x). As I reflect on the concept of "relationality" (Caine \& Steeves, 2009) in a narrative inquiry methodology and in an Indigenous methodology (Wilson, 2001), I feel I am able to demonstrate "significance of and reverence for spirituality, honouring teacher and learner responsibilities, and practising a cyclical type of reciprocity" which are "important lessons ... for those interested in First Nations/Indigenous methodology" (Archibald, 2008, p. x). I also feel more capable of upholding the principles that Kirkness and Barnhardt (1991) spoke to in "First Nations and Higher Education: The Four RsRespect, Relevance, Reciprocity, Responsibility." I saw possibilities when I imagined entering into relationship alongside people rather than beginning research on participants or on Aboriginal issues (Connelly \& Clandinin, 2006). Stewart-Harawira (2005) explained it in the following way:

Reciprocity recognizes that nothing occurs without a corresponding action. Reciprocity means deeply acknowledging the gifts of the other and acting on this recognition in ways which deeply honour the other. At its deepest and most fundamental level, reciprocity requires that we acknowledge and honour the "being" of the other. (p. 156)

The principles of respect, relevance, reciprocity, and responsibility Kirkness and Barnhardt spoke of were an abstract ideal until I sat across from a relative with whom I had shared a history and who opened her heart and shared her stories. As I held people's stories in my hands, I realized what an honor and a deep responsibility I had now to care for them (Lopez, 1990). 
I also feel a responsibility to try to share this knowing. Through discussions with my go-to girls and with other friends and family members, I have learned my story is not unique to me; others experience similar tensions. Narrative inquiry is coherent with the ethical responsibilities I feel for research with humans, especially when engaging in research with Indigenous communities. In Indigenous research methodologies, one has to consider "all [their] relations" (Wilson, 2001, p. 177) when completing the final research text. It also includes striving to "live the good life" as Cajete (1994, p.46) described it. I imagine that I am getting closer to becoming mindful of all who will be impacted by my thesis, by this research text, by this autobiographical narrative inquiry, by my stories. From the inquiry process, I am more able to see possibilities of engaging in Indigenous research, never arrogant with confidence and self-assurance but with a quiet determination that as long as I strive for this good life and am mindful of respect, responsibility, and reciprocity, I will more likely "do no harm," and I can imagine engaging in further research. Holding me accountable is the relational ontology, the research inquiry space, and the writing for and the keeping in mind of the need to benefit "all my relations" (Wilson, 2001, p. 177).

Today, over a year since I last sat across from my relatives asking them to trust me with their stories, I am still deeply impacted by what I learned in that space, in those conversations, and in the months that followed. The more I speak with other family members and fellow graduate students, the more I realize how closely interwoven all of our lives really are and how my stories impact the web that connects us all. As noted by Setterfield (2006),

Human lives are not pieces of string that can be separated out from a knot of others and laid out straight. Families [all our relations] are webs. Impossible to touch one part of it without seeing the rest vibrating. Impossible to understand one part without having a sense of the whole. (p. 59)

The importance of stories shared and safe spaces created to do this sharing is evidenced when my own personal lived experiences resonate with the stories I hear, in the relief of the listener as I describe my unease, and in the pleas of others for me to tell more so they too can feel a validation of their own story. These experiences remind me, in my moments of doubt, that our stories do indeed vibrate across the web and impact in ways that I will never be able to comprehend.

My master's degree was much more than the stepping-stone that many see it to be, much more than only a moment in the grand prize of a higher degree. For me, 
through the inquiry processes of reliving and retelling of my lived experiences, I have been able to come to a deeper understanding of the importance of stories in Indigenous research. I have come to see how my relational way of being, my narrative inquiry, the temporal nature of my chosen methodology, and the way I understand the world through stories is absolutely coherent with Indigenous research and with an Aboriginal worldview. The reflection on my graduate studies experience has allowed me to see how my intellectual knowing of Aboriginal culture continues to emerge; however, my embodied knowing has always been there, and only now can I see it and understand what it is that I live.

Through these moments of sharing stories between cousins, distanced by time and now reunited, I have come to believe that the story itself should be the teacher (Archibald, 2008). There were stories told to me in those interviews with my cousins that brought me back to our youth and a life that held hardships and tears, stories that would break hearts, but they also reminded me of the strength of the women we have become. They reminded me of the love that sustains a family through those kinds of moments and the gift of laughter and humour that is also characteristic of our family. As each one of us shared hard stories, we did so from a place where we either were planning or were already in the midst of our own educational journey as adults. I found hope and inspiration inside the stories of women who statistically were not supposed to survive the educational system that created such tensions but who instead were now role models for their own children and who continued to brave the sometimes uneasy landscape of school. As we shared our stories, finding more similarities than differences, I saw our strength, as a circle of women, grow. I felt the power each story held and the importance of sharing this knowing we held, even if we had not yet finished our own educational journeys. I found a community in which I belonged, and together we found inspiration in each other's stories and validation of our own.

I started my master's degree uneasy at the image of returning to my community as a researcher, intending to take stories from them to benefit my own educational journey. Through narrative inquiry I found not only a way of negotiating entry back into the communities I had drifted away from and into relationships I had thought lost forever, but also a space where I could feel safe enough to become the Indigenous researcher I imagine I want to become. I am still, and likely always will be, in the process of becoming this Indigenous researcher I imagine, but as I strive to become her, I keep in mind Wilson's (2001) words: "As a researcher you are answering to all your relations when you are doing research ... you should be fulfilling your relationships with the world around you" (p. 177). Sharing the knowing from my 
autobiographical narrative inquiry is my way of sharing the importance of narrative inquiry, Indigenous research, and relational ways of engaging in research alongside humans while honouring the knowing they bring in the form of stories. It is my way of not just taking stories but sharing what I have been privileged to learn. I do this from my firm belief that for me and my relations, the stories we told and the stories I retell are indeed "saving stories": stories we can tell "to [ourselves], to [our] friends, sometimes to strangers. Because they make [us] laugh. Because they are a particular kind of story. Saving stories, if you will. Stories that help keep [us] alive" (King, 2003, p. 119).

\section{Notes}

1. "We negotiate relationships, research purposes, transitions, as well as how we are going to be useful in those relationships" (Clandinin, 2006, p. 48).

2. "Right or wrong; validity; statistically significant; worthy or unworthy: value judgements lose their meaning. What is more important and meaningful is fulfilling a role and obligations in the research relationship — that is, being accountable to your relations" (Wilson, 2008, p. 77).

3. Wounded learner-as explained in Lange and Chovanec's (2010) unpublished paper: "Wojecki (2007) also identified learners with internalized feelings of failure and negative dispositions to learning, as individuals who have experienced 'wounding learning practices.' He declines to use the term 'wounded learner,' suggesting it implies an internalized perspective and individual 261 deficits. However, we are using the term to express the structural dynamics that create learning conditions in which some are deliberately wounded within a system where failure is necessary. Rather than believing they are losers who do not deserve better, do not have any academic abilities, and are solely to blame for their own failures, they can see the symbolic violence of a system that victimizes and pathologizes them, within a system where education is used to jostle for social positioning" (Goldstein, 2005, p. 5).

4. "The bottom line is the education of students is suffering and we can't risk losing a generation of young people" (Alberta's Educational Minister Dave Hancock, quoted in "Education Minister Fires School Board," 2010). The minister is referring to a decision to dismiss the entire Northland's School Division School Board and the resulting media coverage of the event. His statement storied Aboriginal people, and especially their children, as "lost." 


\section{References}

Archibald, J. A. (2008). Indigenous storywork: Educating the heart, mind, body, and spirit. Vancouver, BC, Canada: UBC Press.

Barton, S. S. (2004). Narrative inquiry: Locating aboriginal epistemology in a relational methodology. Journal of Advanced Nursing, 45(5), 519-526.

Caine, V., \& Steeves, P. (2009). Imagining and playfulness in narrative inquiry. International Journal of Education \& the Arts, 10(25). Retrieved April 19, 2011, from http://www.ijea.org/v10n25/

Cajete, G. (1994). Look to the mountain: An ecology of indigenous education. Durango, $\mathrm{CO}$ : Kivakï Press.

Clandinin, D. J. (2006). Narrative inquiry: A methodology for studying lived experience. Research Studies in Music Education, $27(1), 44-54$

Clandinin, D. J., \& Connelly, F. M. (2000). Narrative inquiry: Experience and story in qualitative research. San Francisco: Jossey-Bass.

Connelly, F. M., \& Clandinin, D. J. (2006). Narrative inquiry. In J. Green, G. Camilli, \& P. Elmore (Eds.), Handbook of complementary methods in education research (pp. 375-385). Mahwah, NJ: Erlbaum.

Education minister fires school board to address poor student performance. (2010, January 21). Retrieved April 19, 2011, from http://edmonton.ctv.ca/servlet/an/local/C TVNews/20100121/edm_school_100121/ 20100121/?hub=EdmontonHome

Greene, M. (1995). Releasing the imagination: Essays on education, the arts, and social change. San Francisco: Jossey-Bass.

Hancock. D. (2010). Education minister fires school board to address poor student performance (CTV.ca article). Retrieved April 19, 2011, from http://edmonton.ctv.ca/ servlet/an/local/CTVNews/20100121/ed m_school_100121/20100121/?hub=Edm ontonHome
Kahakalau, K. (2004). Indigenous heuristic action research: Bridging western and indigenous research methodologies. Hülili: Multidisciplinary Research on Hawaiian Well-Being, 1(1), 19-33.

King, T. (2003). The truth about stories: A native narrative. Toronto, ON, Canada: House of Anansi Press.

Kirkness, V. J., \& Barnhardt, R. (1991, May). First nations and higher education: The four R's-respect, relevance, reciprocity, responsibility. Journal of American Indian Education, 30(3), 1-15.

Lange, E., \& Chovanec, D. (2010, June). Wounded learners: Symbolic violence and dreamkeeping among marginalized adults. Paper presented at the Canadian Society for the Study of Education Conference, Montreal, QC, Canada.

Lopez, B. (1990). Crow and weasel. San Francisco: North Point Press.

Loppie, C. (2007). Learning from the grandmothers: Incorporating indigenous principles into qualitative research. Qualitative Health Research, 17(2), 276-284.

Mendelson, M. (2006). Aboriginal peoples and postsecondary education in Canada. Ottawa, ON, Canada: Caledon Institute of Social Policy.

Setterfield, D. (2006). The thirteenth tale. New York: Washington Square Press.

Stewart-Harawira, M. (2005). Cultural studies, indigenous knowledge and pedagogies of hope. Policy Futures in Education, 3(2), 153-163.

Wilson, S. (2001). What is an indigenous research methodology? Canadian Journal of Native Education, 25(2), 175-179.

Wilson, S. (2008). Research is ceremony: Indigenous research methods. Halifax, NS, Canada: Fernwood. 


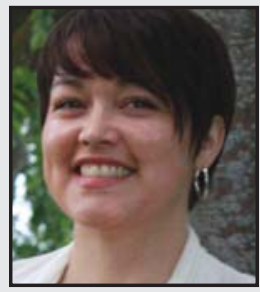

Trudy Cardinal is a PhD student at the University of Alberta in the Elementary Education Curriculum studies program. A Cree/Metis woman, she originated from rural communities in northern Alberta and currently teaches part-time while engaging in research in the area of Aboriginal education. She obtained her M Ed degree in Indigenous People's Education at the University of Alberta in September of 2010. 